\title{
A Geologic Matching of The Soil Categories and Their Geo- chronological Rock Units Covering The Sinai Peninsula Using GIS,Sinai, Egypt
}

\author{
Nader A. A. Edress* and Maysa M. N. Taha \\ Geology Department, Faculty of Science, Helwan University,Egypt
}

\begin{abstract}
OILS of Sinai show development of soil group from ancient Precambrian dominated parent rocks at south into stratigraphy younger Quaternary coastal deposits in the north. Five groups and eight soil classes are distinguished in the study area, according to world reference base for soil resources. They are leptosols (35\%), calcisols (34\%), arenosols (17\%), regosols $(10 \%)$, and solonchaks (4\%) soil group cover Sinai Peninsula. Leptosols soil classes characterized by present of stiff hard rock units of dominated Precambrian basements for lithic leptosols soil class or Mesozoic and Tertiary rocks for eutric leptosols soil class. Cretaceous, Tertiary and Quaternary strata represent the main essential parent rocks for haplic yermic calsiols class of $98.93 \%$ while the haplic calsisols class comprises mainly of Paleozoic composed of $73.44 \%$. Both classes characterized by the same component of rich carbonate Formations. Arenosols composed of sand dunes with relic of high elongated folds emerge from it. The calcaric arenosols soil class may represent the end course of transportation agent came from the hinterland area from south. Due to effect of water seepage from Mediterranean, sea sabkha are formed to separate the gelyic solonchaks class from the former arenosols one. Unconsolidated material of regosols soil groups composed unconsolidated clastic deposits of eutric regosols class and calcaric regosols class.
\end{abstract}

Keywords: Leptosols, Calcisols, Regosols, Arenosols, Solonchaks, Sinai, Egypt

\section{Introduction}

Soil is the outermost layer of the earth, which consists mainly of detrital solid mineral and organic matter. It formed from the effect of physical and chemical weathering on the parent rock. These processes are often of exfoliation, unloading, saltation, thawing and freezing for physical weathering and hydration, carbonization, and oxidation for chemical weathering those took place under the action of climate, geological, biological and topographic influences. (Coleman, et. al., 2004; Pansu and Gautheyrou 2006; Nichols, 2009; Leeder, 2012). Many organizations made an international standardization system for studding and systematic classification of worldwide soil profiles (FAO/ UNESCO, 1971-1981; USDA, 1975, 1999; ECSC-EEC-EAEC, 1985; EC, 2005; IUSS Working Group WRB 2006; World reference base for soil resources, 2014).
More accepted guidelines for Soil description are (FAO, 1990) Schoeneberger et. al., (2002), USDA Soil Survey Staff, (2003) ISRIC, (2005) and IUSS Working Group WRB (2006). One of the famous soil description and classification of soil guideline is FAO (2006) that mentioned five comprehensive stages for studying soil range from registration, location into stage two of soil formation factors, observation and measuring of horizons, into genetic and ecologic interpretation and finally suitability evaluation. Soil is a function of parent material, topography, climate, vegetation, human activity and time (Jones et. al., 2013). Parent material refers essentially to the different types of rock and sediments from which soil is derived. So, lithological characters of different rock are a mirror for the mineralogical composition of present soil formed. In mountainous areas or in arid zones like aridity map of world (Leeder. 2012), it shows clear

"Corresponding author email: (nedress@outlook.com)

DOI: 10.21608 /ejss.2018.2279.1146

C2018 National Information and Documentation Centre (NIDOC) 
evidence of any ongoing soil forming processes, other than the weathering of the parent material. Resemble for the study areas, it may be difficult to find of nature generating of soil profile development horizons. So comprehensive studied te soil profile can be negligible as a consequence of the young age and/or slow rate of development of pedogenic processes due to unfavorable aridity and absent of vegetation cover.

Accordingly, the main target of this study is to focus on the stage II for soil reconnaissance restricted to parent material of rocks and sediments and their ages as an important factor in soil formation. An attempt to updating the definition of soil nature at high levels of soil taxonomy and classification within Sinai Peninsula, according to IUSS Working Group WRB (2006) and World reference base for soil resources (2014) is also included. The derived knowledge of the genesis of soil will help further researcher as a base data to explain types of weathering and its mineralogical composition. As well as, it will give accurate place for next stage international guideline of sampling and determine the most popular sites for comprehensive studies of soil profile for more detail soil researches within Sinai Peninsula.

Morphological and stratigraphic description of the study area

The Sinai Peninsula is triangular in shape covers an area of $61,000 \mathrm{Km}^{2}$ linking Africa to Asia. It geographically great extend land extend for about $210 \mathrm{Km}$ from east to west and $385 \mathrm{~km}$ from north to south. It is situated between the Suez Canal and Gulf of Suez on the west and the Dead Sea and Gulf Aqaba on the east. It is bounded on the north by the Mediterranean Sea and on the south by the Red Sea (Fig. 1).

Foremost parts of the Sinai Peninsula are rocky and flat with slightly cutting valleys draining either toward the Gulfs of Suez or Aqaba. It encloses stratigraphic section ranges in age from the Precambrian to Recent of accumulated thickness of strata run from $2000 \mathrm{~m}$ to $8000 \mathrm{~m}$ northward (Said, 1962; EGPC, 1986; Alsharhan and Salah, 1996; Amar and Afifi, 1992; Issawi et. al., 1999, Tawdros, 2001) (Fig. 2). The basement complex occupies the southernmost part of the Sinai Peninsula of so called Sinai badlands. It represents by the highest altitude very rugged igneous and metamorphic mountains of Gebel Katherina (2,641 m, a. s. 1.), Gebel Umn Shomer $(2,586 \mathrm{~m}$, a. s. 1.) and Gebel Serbal (2,070 m, a. s. 1.) (Said, 192; 1990; Issawi, 1999). More than ten basements rock units were grouped and detailed descripted on the geological map of Egypt (1981) of gneisses and migmatites, older metasediments, older metavolcanics, serpentinites, older gabbros, older granitoids, Dokhan volcanic, younger metasediments, younger gabbros, younger granitoids, post-Hammamat felsites, ring dike complexes and swarm dikes, and quartzites and arkosic sandstones (Said, 1971, EI Gaby et. al., 1990 and Hassan \& Hashad, 1990).

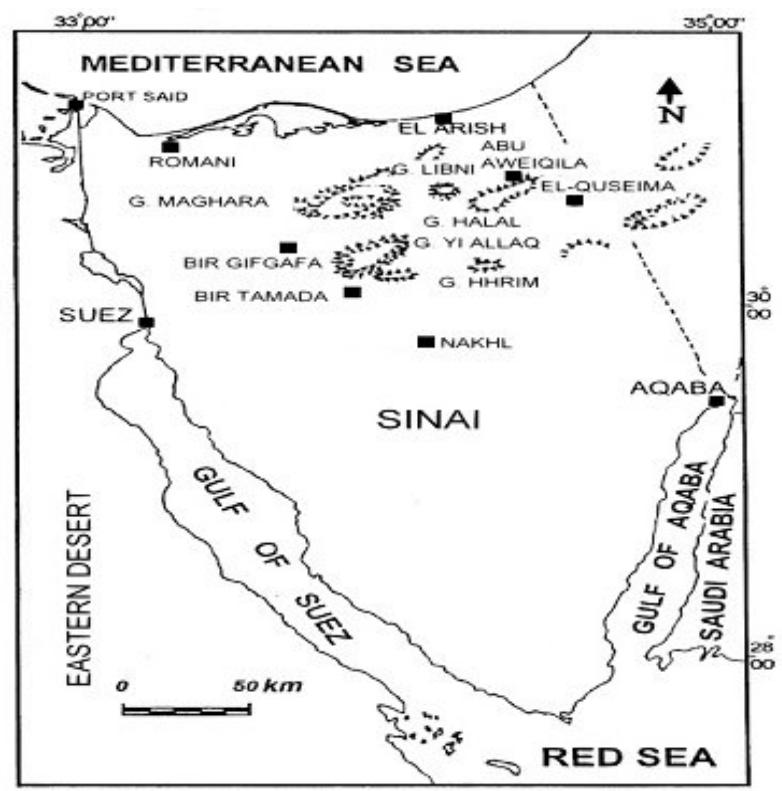

Fig. 1. Location map of Sina Peninsula (Said 1990) 
Toward the north, at the central parts south of Egma plateau, a thick sedimentary rock deposited in structurally graben. The Egma plateau covers most of central Sinai of surface elevation is (1000 $\mathrm{m}$, a. s. 1.). This plateau composed mainly of chalky to siliceous and dolomitic lithofacies topped by lower Eocene limestone and chert nodules (Issawi, 1999). North of Egma more extended plateaus is named the Tih to the west and El Hazim to the east with a lower average elevation of $(900 \mathrm{~m})$ and $(700 \mathrm{~m})$ respectively. They formed together a bulk succession of sub horizontal strata of Mesozoic and Tertiary. Many Wadis within this plateau connected together to form a giant Wadi El Arish which continued its course to northern Pedipalin central Sinai into the Mediterranean Sea of $180 \mathrm{Km}$ long. Abdel Rahman and Onsi (1996) distinguished four subclasses of soil in these area flood plain, wadi terrace, gravelly plains and playa.

The Pediplains area lies north Egma plateau to elevated northern Sinai fold belt of Gebel Yi Allaq, G. Maghara, G. Libni, G. HHrim, and G. Halal (Fig. 1). This nearly flat area of $55 \mathrm{~km}$ from south to north composed mainly of Upper Createous rocks below disseminated outcrops of Eocene Limestone. The rest of the extreme northern area of the Sinai peninsula composed of coastal Mediterranean plain where the dunes are dominated with seepage of sea water in low areas and sabkha of Recent deposits. Arenosols type is the most common soil of this area. The calcareous soils generally dominated along the coastal littoral of Egypt as well as in Sinai (Yigini et. al., 2013). Saleh et. al. (2013) mentioned that soil characteristics in the northern part of the Sinai are mostly on calcareous soils, solonchaks of dry and wet sabkhas, and sand dunes represented arenosols.

Except the basement outcrop the sedimentary outcrop covers the two third parts of the Sinai Peninsula flanking from an altitude of $1000 \mathrm{~m}$ of Egma plateau to few meters close to the sea level. Onshore drilling wells along the Mediterranean coastline of Sina Peninsula recorded subsurface strata thickness of about $6000 \mathrm{~m}$ (Schlumberger, 1984), From which the most Formation of litho-stratigraphic section of the Sinai are determined (Fig. 2).

\section{Material and Methods}

\section{Mapping data and analyses}

The digital mapping of soil map and geologic map resources is invigorated by the progress Geographic Information System (GIS). Information obtained from both sources of data analysis and statistics calculated area was added to the database map, and GIS was used to give a relationship by prepare, calculate and combined each high taxonomy soil and rock Formation unit areas together. ArcGIS version 10.4.1 software was used to accomplish this study. Geologic map of Egypt (1981) of scale 1:2 000000 are used as a main source of parent material with Geologic map of Sinai, Arab Republic of Egypt (1992), including varieties of rock units within Sinai Peninsula from Precambrian basement complex into a Phanerozoic stratigraphic succession of different age (Fig. 2). To facilitate lithologic descriptions of rock units in our studies we used generalized lithostratigraphic section of the Sinai Peninsula (Schlumberger, 1984; EGPC, 1994) (Fig. 2). For construction of soil base map (Fig. 3), many resources are combined to give more accurate definition of soil taxonomy digital map for the study area, including soil map of the World of scale 1:5 000000 by the FAO/Unesco (1971-1981) Volumes 1-legend, VI-Africa, and VII-south Asia, technical paper 20-soil map of the World (FAO/Unesco/ISRIC, 1997), guidelines for soil profile description (FAO, 1990), Soil map of Africa (bar scale, 0-2400Km) (FAO, 1991), IUSS Working Group WRB (2006); World reference base for soil resources (2014).

\section{Results and Discussion}

Systematic soil classification is essentially based on combination of soil characteristics in relation to their Geo-chronological Formations and Rock units. The rules for natural soil classification categories used in this study is differ than the technical classification of certain purpose. It allows distinguishing and predicting features resulting from soil forming processes from those origins in term of genesis geological aspect. From about thirty two major groups of world reference base for soil resource, five groups and eight classes are distinguished in the study area. They are leptosols, calcisols, regosols, arenosols, and solonchaks soil group cover Sinai Peninsula (Fig. 3). From which lithic and eutric is two different soil classes derived from the leptosols soil group are determined, eutric and calcric classes of regosols soil group, and haplic and haplic class (yermic) of the calcisols soil group are also presented. Other two soil groups represented by only one class like a gleyic class of solonchaks soil group and calcaric class of arenosols soil group (Fig. 3).

The Leptosols soil group is the most common soils in the world refer to much mountain soil in all climatic zones. Its name derived from Greek (leptos mean thin) with less than $100 \mathrm{~cm}$ from the

Egypt. J. Soil. Sci. Vol. 58, No. 2 (2018) 


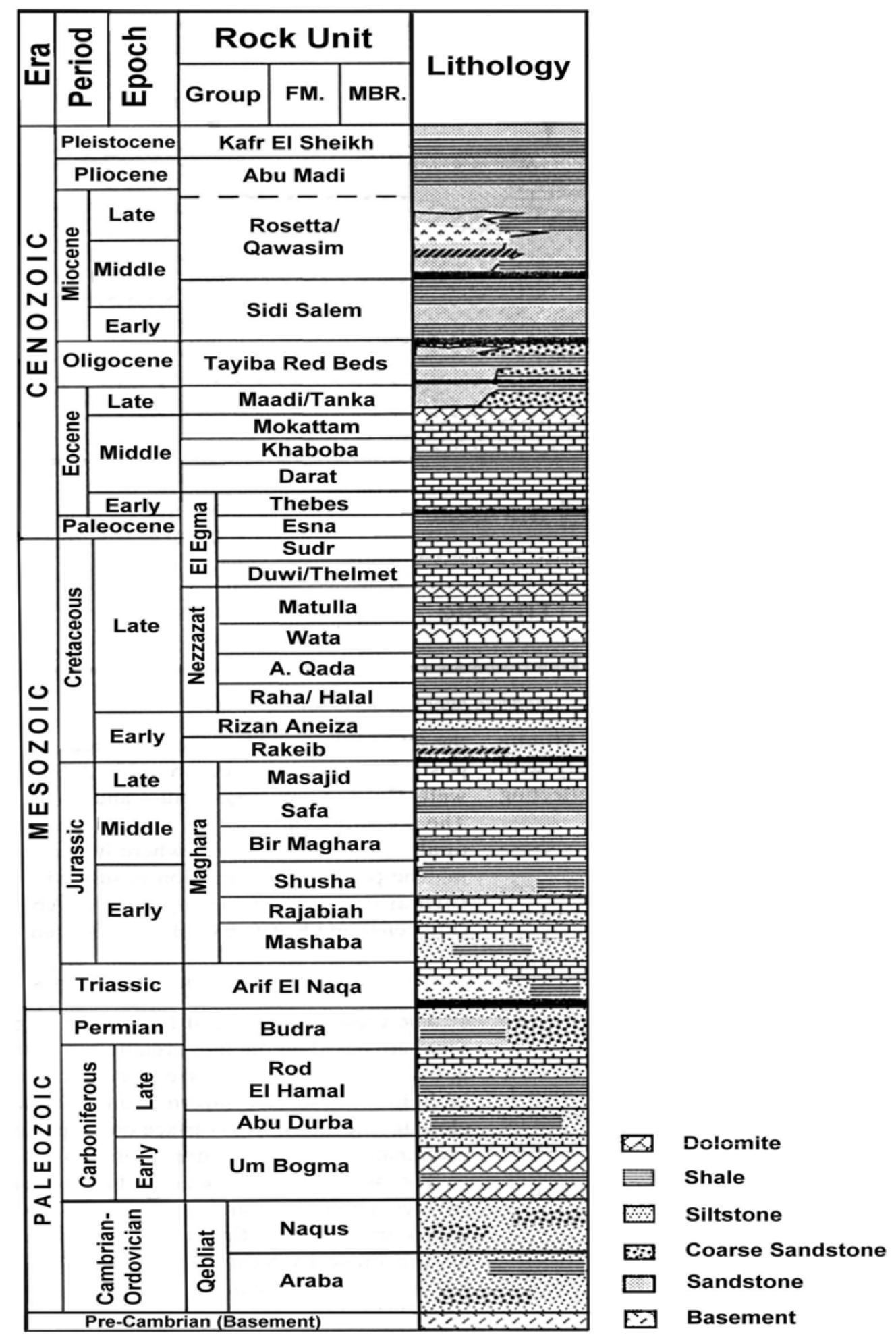

Fig. 2. Generalized lithostratigraphic sections of Sinai Pennsula (Schlumberger, 1984; EGPC, 1994) 


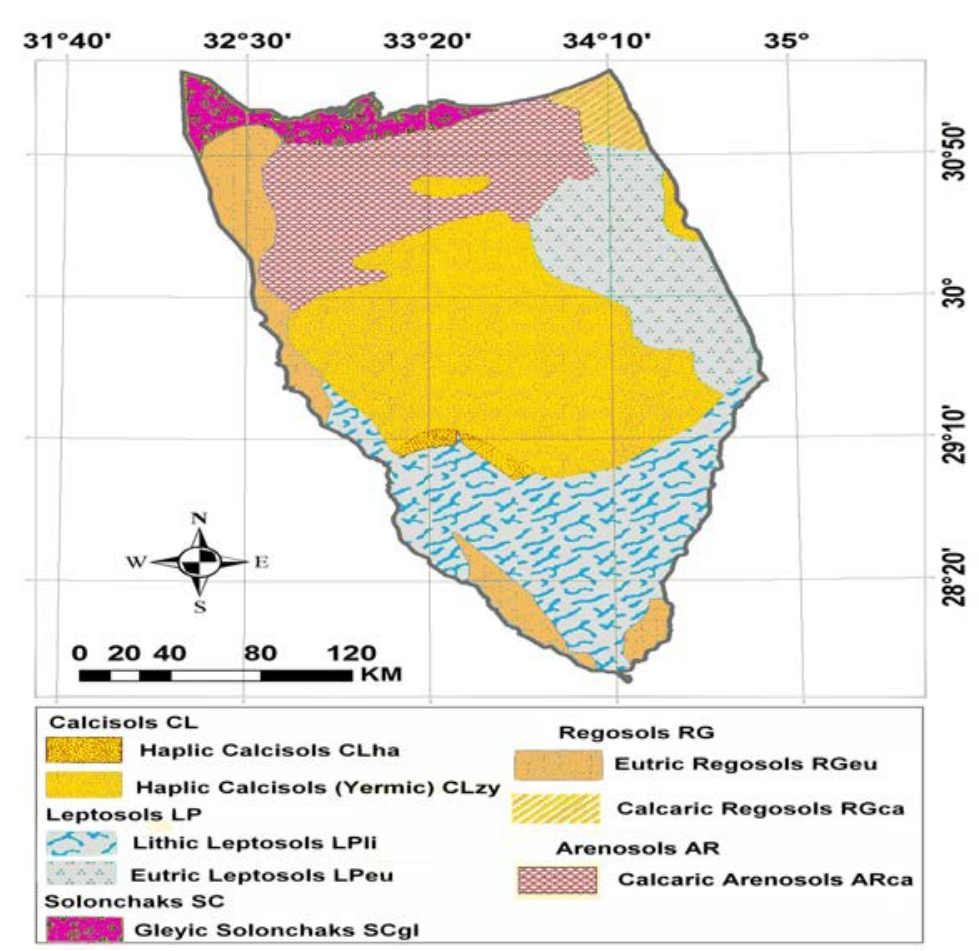

Fig. 3. Soil map of the Sinai Peninsula with standard color and abbreviation drawing using GIS according to World reference base for soil resources (2014)

Note: Hachuring not coincides with international standard is added to facilitate separation of soil categories.

soil surface. Shallow soil on a steep slope is the most common topographic features of leptosols. If characterized by various kinds of continuous rock Parent material of hard rock, very gravelly material more than $80 \%$, or highly calcareous deposits with finest grain size must not exceed $20 \%$ by volume (ISSS Working Group RB, 1998). In most arid zones and Sahara like to study area, it clearly covers rocks that are resistant to weathering in addition of wind erosion of continuous rock its thickness not exceeds $10 \mathrm{~cm}$ depth and represents the most extensive Leptosols. Leptosols hard rock in the study area may expose or comes close to the surface and the physical weathering of degradation and disintegration of parent rocks due to or heating/cooling cycles is the main soilforming processes.

In soil classification and taxonomy seven different soil classes derived from leptosols. They are Gelic (the cold ones), Lithic (Shallow soil cover hard continuous rock with less than 10 cm soil depth ), Rendzic (dark surface with high $\mathrm{CaCO} 3$ ), Umbric (has umbric horizon), Mollic (has mollic horizon), Eutric (soil very limit depth cover hard rock, no acid) and Dystric Leptosols (Batjes et. al., 1997; FAO/ISRIC/ISSS, 1998; USDA, 1999; Nachtergaele, 2010; IUSS Working Group WRB, 2006; World reference base for soil resources, 2014). In the study area, leptosols is the most dominated soil groups of the Sinai Peninsula (Fig. 4). It covers an area of approximately 21 thousand square kilometers represent the $34.6 \%$ of the Sinai territory. It covers the area between latitude $27^{\circ} 40^{\prime}-30^{\circ} 55^{\prime}$ north and longitude $32^{\circ} 45^{\prime}-34^{\circ} 50^{\prime}$ east. If differentiated upon soil taxonomy as lithic leptosols occupies the southernmost part and eutric leptosols of east central and east northern part of the study area.

The lithic leptosols soil class represents the third southern part of the Sinai. Its shape like a triangle pointed to the red sea and its base to north. Basements complex comprises $61.38 \%$ of the lithic leptosols soil class from which older granitods express $30.33 \%$ of the recognized basement subsequent with about $7 \%$ of each MigifHafafit gneisses, metagabbro-diorite complex and younger granitoids, whereas the rest area of the basements occupy by the other Precambrian rock units with low percentage area less than $2 \%$. Paleozoic strata comprise the lithic leptosols soil class are represented by the low percentages covered area of Paleozoic (5.37\%) mostly of Carboniferous uppermost dolomite and clastics of the Um Bogma Formation of early Carboniferous age (Fig. 2). Mesozoic Era represented in this soil class by only Cretaceous Period represented 
$11.6 \%$ of soil cover dominated by early and the late Cretaceous formation started by intercalated of continental clastic into well developed and differentiated formation of marine carbonate beds. Mesozoic of Tertiary Period represented an area of $7.79 \%$ in which Miocen of (4.6\%) and Eocene of $(1.8 \%)$ are dominated. Quaternary wadi deposits cutting the main mountain ranges of basement and transported disintegrated clastic represented $12.84 \%$ of the lithic leptosols soil class.
Accordingly, the soil forming process and formation in this type under arid climatic condition is depended essentially on the hardness of igneous and metamorphic rocks that compose the entire percentage of such soil class. Any plain of weakness such as; foliation, cleavage, joints, fissures, and intrusive contacts can promote or enhance physical degradation. However, with optimal circumstances of degradation, the rate of soil formation in such case will be still very slow. In contrast, the lithic leptosols class as

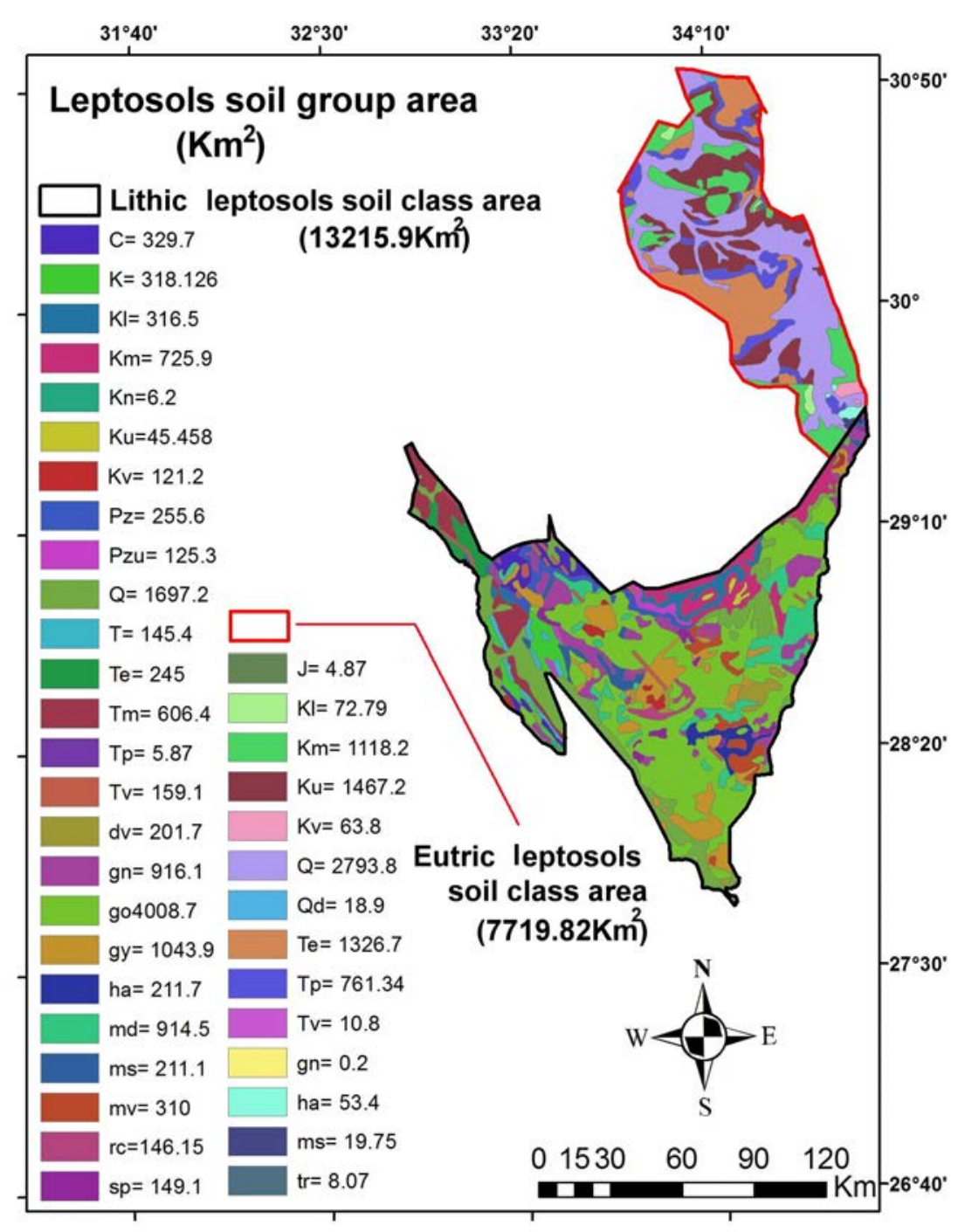

Fig. 4. Leptosols soil group area and their enclosing Geo-chronological rock units

Precambrian: gn, M igif- $\mathrm{H}$ afafit gneisses and migmatite; ms, metasediments; mv, metavolcanic; sp, serpentinite; md, metagabro-diorite; go, older granitoids; dv, D okhan volcanic; ha, H ammamat group. Paleozoic: C , C arboniferous; Pzu, post-C arboniferous. M esozoic: Tr, Triassic; J, Jurassic; K, C retacous; KI, L ower Cretaceous; Km, N ubia Fm-Upper Cretaceous; Kn, Upper Cretaceous; $\mathrm{Ku}$, undivided Cretaceous. Tertiary: T, Paleocene-E ocene; T p, Paleocene; Te, E ocene; T v, Teriary volcanic. Q uaternary: q, undivided Q uaternary; Q d, sand dunes.

Egypt. J. Soil. Sci. Vol. 58, No. 2 (2018) 


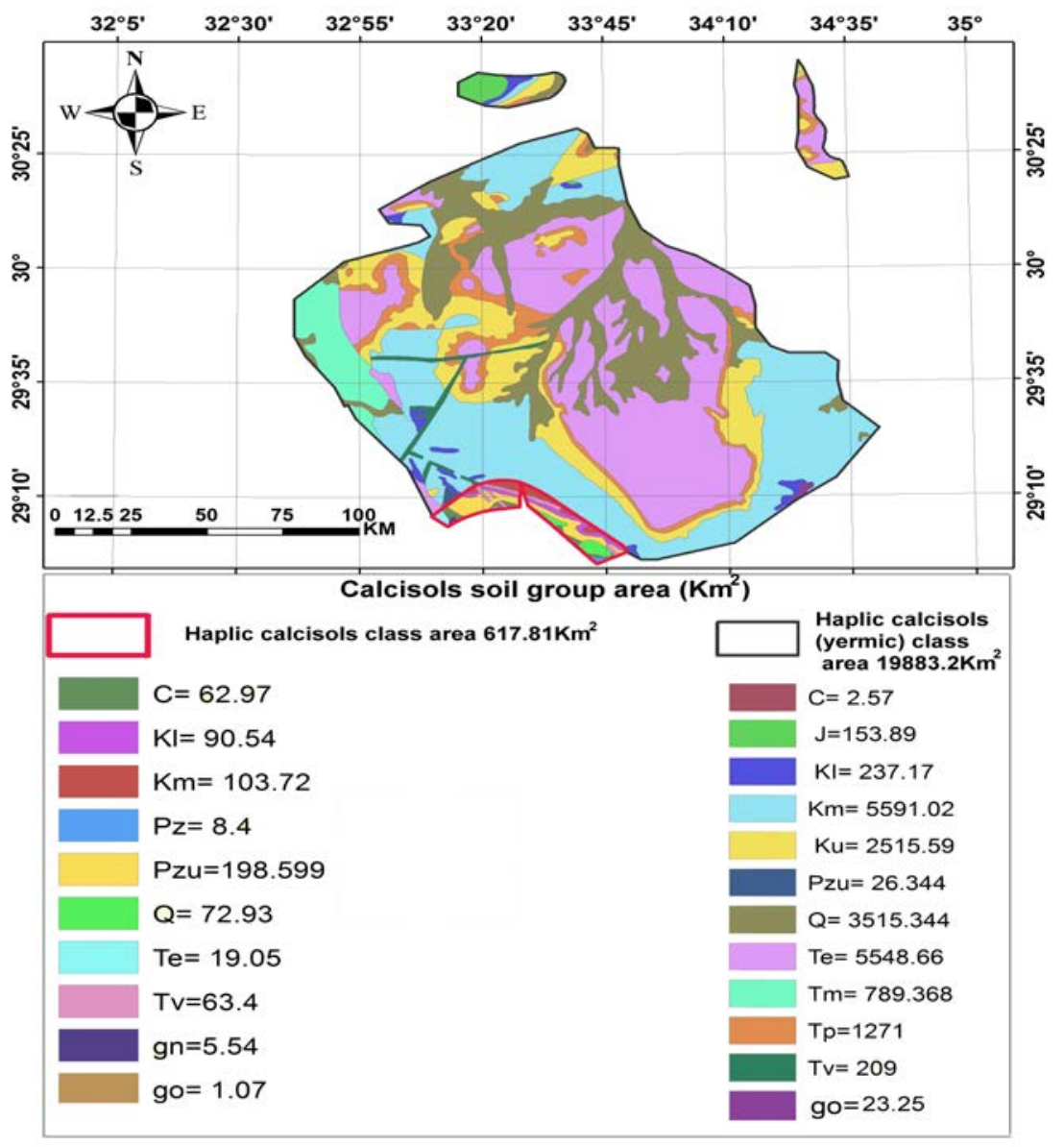

Fig. 5. Calcisols soil group area and their enclosing Geo-chronological rock units

Precambrian: gn, M igif- $\mathrm{H}$ afafit gneisses and migmatite; go, older granitoids; Paleozoic: C, Carboniferous; Pzu, postC arboniferous. M esozoic: $\mathrm{Tr}$, T riassic; J, Jurassic; $\mathrm{K}, \mathrm{C}$ retacous; $\mathrm{KI}$, L ower $\mathrm{C}$ retaceous; $\mathrm{K}$ m, $\mathrm{N}$ ubia F m- $\mathrm{U}$ pper $\mathrm{C}$ retaceous; $\mathrm{Kn}$, U pper C retaceous; $\mathrm{Ku}$, undivided C retaceous. Tertiary: T, Paleocene E ocene; T p, Paleocene; Te, E ocene; T v, Teriary volcanic. Q uaternary: q, undivided Q uaternary; Qd, sand dunes.

mentioned rich in Basements complex the eutric leptosols composed mainly of less than $1 \%$ of Precambrian Basements. Outlines of this soil class dominated by stiff hard strata of Mesozoic especially Cretaceous of carbonate beds (35.25\%) and Tertiary $27.18 \%$ of Paleocene $(9.8 \%)$ of massive shale and Eocene (17.18) of thick marine limestone from lower Eocene Thebes Formation to Upper Eocene Tanka/Maadi Formation (Fig. 2 and 4). Quaternary sand and dunes increase in this soil class into $36.44 \%$ due to decrease the hardness of sedimentary rock in comparing to the hardness of Basements. Waltham (2009) experimented the intact average unconfined compressive stress for igneous and metamorphic rock of about $200 \mathrm{Mpa}$, while the maximum resembles more resistance intact limestone and carbonate strata is $100 \mathrm{Mpa}$. The latter fact show the capability of lithic leptosols soil to permit soil formation process is twice more than that of eutric leptosols soil under routine coursed of physical weathering.

Calcisols refers to soils with considerable accumulation of calcium carbonates its name derived from latin (calcarius) of lime rich deposits. It's widespread in arid and semi-arid environments, with the parent rock of carbonate or calcareous rich sediments. Calcisols mostly formed in desert process with the pale brown surface horizon. Carbonate occurs secondary carbonate within $100 \mathrm{~cm}$ of the soil surface (IUSS Working Group WRB 2006; World reference base for soil resources, 2014). 
Accumulation of carbonate must occur at enough dry climate by either leaching of carbonate from upper part of the soil when the soil oversaturated with carbonate rich water moving through soil during streams or by evaporation of water, leaving calcium carbonate cement filling pore space to form hard calcrete soil hard pan (Jones et. al. 2013). The calcisols soil group is the most next dominated soil group of the Sinai Peninsula (Fig. 5). It covers an area of approximately 20.5 thousand square kilometers represent the $33.8 \%$ of the Sinai land. It covers the area between latitude $28^{\circ} 55^{`}-30^{\circ} 43^{`}$ north and longitude $32^{\circ} 40^{`}-34^{\circ} 45^{`}$ east. If differentiated upon soil taxonomy as a calcisols soil group occupies the most central part of Sinai within Egma plateau and its associated El Tih, and El Hazim east and westward plateaus respectively.

It differentiated into two soil class named haplic calcisols class at the structurally graben between southern Egma and Basements, and haplic calcisols (yermic) class extended further north throughout the pediplain area till structurally folded belt in the north. No sharply limitations between the both calcisols classes, they have a significant accumulation of calcium carbonate strata with the exception that the yermic has an observed distribution of rock fragments on the soil surface from aerial images. It may result from high consistency of carbonate rock material forming the haplic calcisols soil (yermic) class than the same carbonate strata of haplic calcisols class. Cretaceous, Tertiary and Quaternary strata represent the main essential parent rocks for haplic calsiols class (yermic). They composed the mainly outcrops of an areas $41.96 \%, 39.3 \%$, and 17.67 in respect order. The Upper Cretaceous from Halal/ Raha Formation into Sudr Formation is dominant $(40 \%)$ with dominated lime strata, Eocene from tertiary comprise $(28 \%)$ it resented from Thebes to Tanks/Maadi Formation of carbonate rich strata, Paleocene and Eocene periods cover $10 \%$ of this soil class, where the waste weathering product of calcareous rich clastic sediments form the rest of Quaternary age (Fig. 2 and 5).

The haplic calcisols class restricted to the southern structure area of relatively small area of about $618 \mathrm{Km}^{2}$ area about $3 \%$ of total the dominated calcisols group. It comprises mainly of Pre-Carboniferous Paleozoic (32\%) and Carboniferous (10\%) strata. Cretaceous is the next parent rock of equivalent lower and upper strata of $(31.44 \%)$. Tertiary comprises 13.34 of mainly volcanic eruptions (10\%) with Eocen 3\% and quaternary (11.8\%) (Fig. 5). The carbonate limestone constituent the haplic calcisols (yermic) may have a higher consistency than those forming the haplic calcisols that may attribute to many reasons, one of them the hardness of younger strata appear to have a higher consistency than the older. That may believe to presence of rock fragment material on the top surface of haplic calcisols class yermic than haplic calcisols class.

Arenosols soil group, from Latin (arena) means sand, usually named for unconsolidated deep sandy soils, in places may calcareous. It came from transporting materials of sandy quartzrich sediments or rock. This includes depositing sands such as dunes in deserts and beach lands. It represented extremely weathered siliceous rock. In the dry climate, there is little or no soil horizon development. Calcaric arenosols class is those sandy soil classes which have a notable levels of calcareous lime (IUSS Working Group WRB 2006; World reference base for soil resources, 2014). The arenosols soil group expresses the third most dominated soil group of the Sinai Peninsula (Fig. 6). It covers an area of approximately 10.3 thousand square kilometers represent the $17 \%$ of the Sinai territory. It covers the area between latitude $30^{\circ} 52^{\prime}-31^{\circ} 11^{\prime}$ north and longitude $32^{\circ} 37^{`}-34^{\circ} 10^{`}$ east. If differentiated upon soil taxonomy as calcaric arenosols class.

It makes up about $71 \%$ of Quaternary Pleistocene and Holocene deposits of sand dunes, sand sheat, palaya, raised beaches. Sand dunes solely composed 28 of the previous percentage. It may represent the end course of sorting and transportation of more resistance quartz mineral which came from the high hinterland area at the south. So that, from the geologic viewpoints the southern rim or the southern first appearance of calcaric erenosols class on the soil map (Fig. 6) is the quite enough distance at which well sorting and mature sediment of essentially more resistance quartz grain are accumulated. The Mesozoic and Tertiary stratum consider the rest $29 \%$ of this soil class. They found as isolated hills or relic of north east folds of Gebel Yi Allaq, G. Maghara, G. Libni, G. HHrim, and G. Halal and others (Fig. 1) embedded within vast area of former calcaric arenosols class. From geologic maps the erosion outcrops of these fold belts exhibit an older strata of Jurassic and Cretaceous at the center and became younger outward by Tertiary strata preferring antifoam fold styles (Fig. 6). 
The solonchaks soil group is the soil of highly concentrated soluble salts. It is name driven from Russian (sol) mean salt rich. It largely confined to high aridity climate zones especially along coastal seas. Many Solonchaks soils have gleyic properties of salt accumulation at the soil surface and relatively depressed area with a shallow water table. Continuous ascending of groundwater by evaporation gives properties of accumulation of salts at some depth below the soil surface IUSS Working Group WRB 2006; World reference base for soil resources, 2014).

Solonchak soil group in the study area organizes the north extension of arenosols soil group with the effect of salt impregnation from the Mediterranean Sea. It sets up $4.4 \%$ of the soil area of Sinai. It composed of entirely $100 \%$ of Quaternary deposits covers the area between latitude $30^{\circ} 46^{\prime}-31^{\circ} 19^{\prime}$ north and longitude $32^{\circ} 11^{\prime}-33^{\circ} 40^{\prime}$ east. It differentiated upon soil taxonomy as gleyic solonchak soil class (Fig. 6). Gleyic solonchaks of Sinai comprises Pleistocene and Holocene deposits of Sabkha (26\%), coastal sand dunes (29\%), and other palya, wadi and sand sheets deposits composed the rest area of (45\%). The Sabkha along the coastal plain is often wetted by sea water during wave from the sea wind agitated or by high tide periods. Area of evaporation established where groundwater drawn up to the sediment surface by seepage from sea to hot surface of the coastal plain (Einsele, 1992). Gypsum and anhydrite horizons within the coastal plain sediment are gradually formed by the crusty surface of halite by the time (Nichols, 2009). Generally, almost all soil forming process has a negative effect in arid environments, except solonchaks soil group types appear to possess an excellent development in such case of coastal and aridity influence. As mentioned above the surface horizon of halite, and subsurface nodules of gypsum and anhydrite is well developed by time in suck case of Sabkha deposits within supratidal zone of so called solonchaks soil group. Gleyic solonchaks soil class of wet surface of waterlogged conditions with salt accumulation is the most differentiated soil under such condition (Fig. 6).

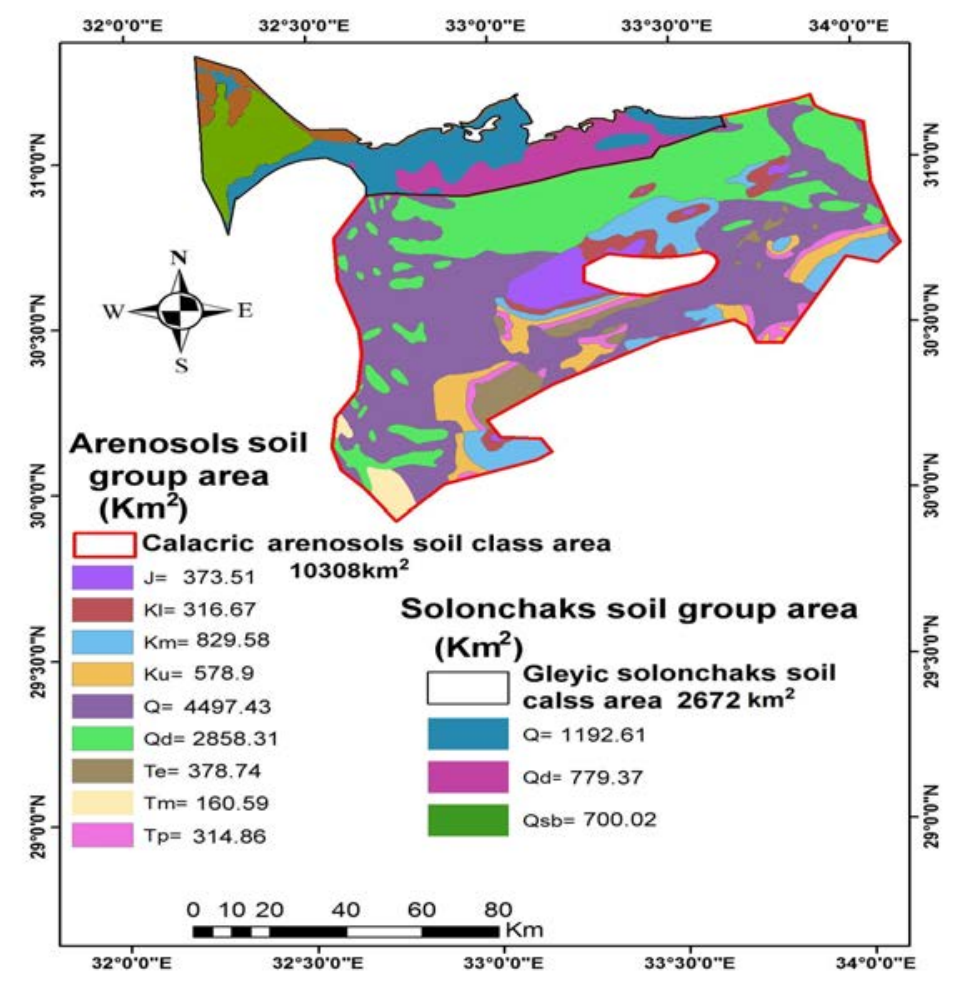

Fig. 6. Arenosola and solonchaks soil group areas and their enclosing Geo-chronological rock units

M esozoic: J, Jurassic; $\mathrm{K}$, C retacous; $\mathrm{K}$ I, L ower C retaceous; $\mathrm{K}$ m, N ubia F m- U pper C retaceous; $\mathrm{Ku}$, undivided C retaceous. Tertiary: T p, Paleocene; Te, E ocene; T m. M iocene; Q uaternary: q, undivided Q uaternary; q, undivided Q uaternary; qd, sand dunes, qsb, sabbka deposits. 
Regosols soil group from Greek (rhegos) mean blanket is a weakly development, mineral soil in unconsolidated materials (generally fine-grained) of medium and fine grained matrix not rich in the coarse fragments like leptosols or sands like arenosols. Its wide spread extensively in eroded area and accumulation zones, especially in dry tropics aridity and mountainous terrains. It don't haven't soil horizon due arid climate in either young age deposits and/or slow soil formation rate. Two taxonomy subdivision of regosols soil group is differentiated in the Sinai Peninsula, eutric regosols class of weakly developed soil in unconsolidated material not acid and calcaric regosols class as the same as eutric with notable levels of lime and carbonate minerals (Fig. 7).

The regosols soil group cover an area of $6137.1 \mathrm{Km}^{2}$ represents $10 \%$ of the soil group of Sinai. It is unlike the other soil group occupying a massive area in soil map as shown in figure (3) but it appears as a long belt along the eastern flank of Suez Canal, two belts like v shaped at the extreme southern part of Sinai along Red Sea, and the eastern isolated patches occupies the central and northern part along the northeastern political rim of the territory of Egypt in Asia (Fig. 7). Eutric regosls class is the significant dominant class of the regosols group in the study area with dominated cover $4849 \mathrm{Km}^{2}$ four times than the distribution cover of calcaric soil class. It is composed of $77 \%$ of unconsolidated clastic deposits of Quaternary age, mainly $73 \%$ of combined clastic and $3 \%$ of sand dunes. The seventeen percentage of the Tertiary mostly Miocene period of Sidi Salem and Rosetts/ Qawasim Formations of dominate sand and shale sedimentary rocks, and the rest $5 \%$ of basement rocks (main source of rock fragment). The calcaric regosols class only restricted to extreme northeastern part of the Sinai as patch area consists of unconsolidated Quaternary deposits represent 91\% (55\% clastic sediments and 36\% sand dunes). The rest percentage of $9 \%$ is of Tertiary of Thebes, Darat, Khaboba, Mokattam, and the Maadi/Tanka Formation of mostly marine hard limestone rock and shale of Eocene periods (Fig. 2; 7).

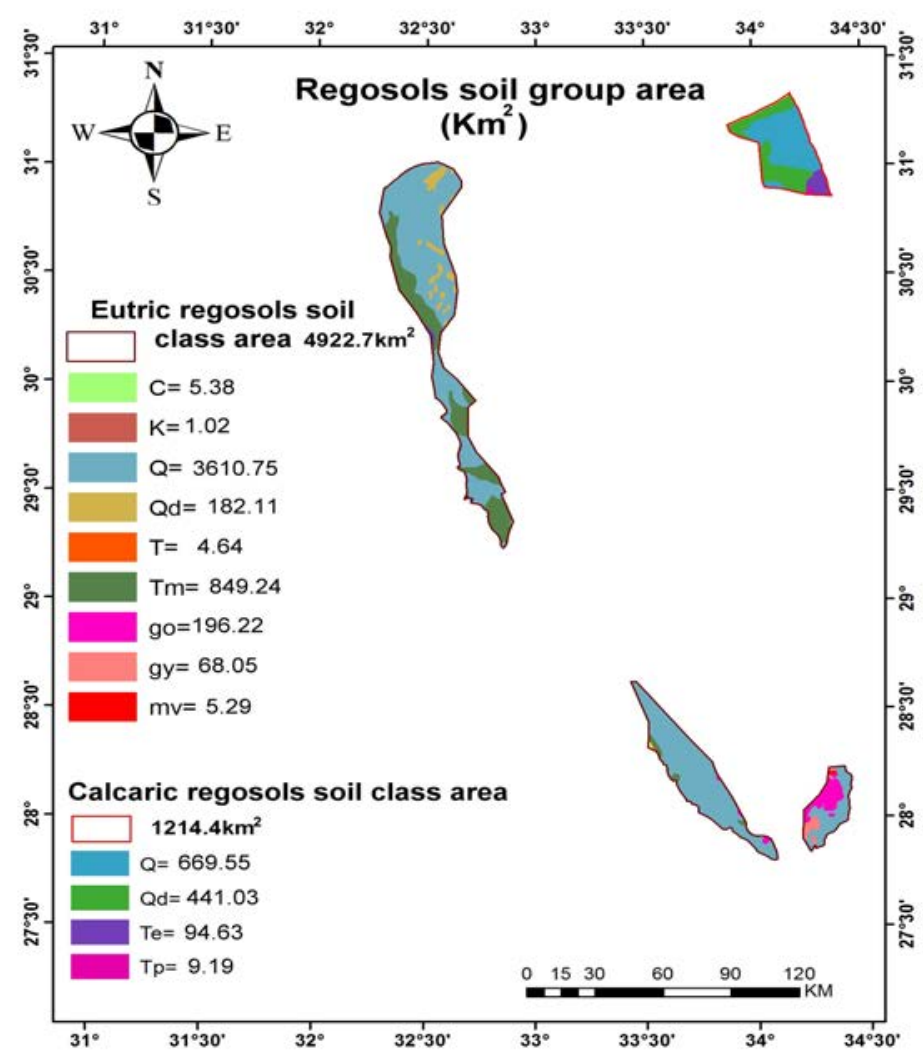

Fig. 7. Regosolos soil group area and their enclosing Geo-chronological rock units

Precambrian: gy, younger granitoids; mv, metavolcanic; go, older granitoids. Paleozoic: $C, C$ arboniferous; $K, C$ retacous; T ertiary: T, Paleocene-E ocene; T p, Paleocene; Te, E ocene. Q uaternary: q, undivided Q uaternary; Q d, sand dunes.

Egypt. J. Soil. Sci. Vol. 58, No. 2 (2018) 


\section{Conclusion}

Five main soil groups are distinguished within a soil map of Sinai. They are leptosols, calcisols, arenosols, regosols and solonchaks soil groups. The percentage of precursor parent rock for soil formation play an important role in distribution area and the types of soil founded. Digital maps established by GIS illustrate the distribution areas for each soil class in addition to give the percentage and types of rock forming each type of the present soil. The Leprosols soil group with the calcisols soil groups represents the dominated soil group cover an area of $35 \%$ and $34 \%$ respectively $(69 \%)$ of the Sinai Peninsula. They associated topography of high Bad Lands for leptosols soil group and dominantly high plateaus for the calcisols soil group. The basement complex of Precambrian age comprises $61.38 \%$ of the lithic leptosols soil class whereas stiff hard strata of Mesozoic and Tertiary constitute 66.68\% of mainly massive thick limestone with many marine formations are the most components of eutric regosols soil class. Quaternary of mostly wadi deposited dissected these mountainous and high land soil areas are the main source of quaternary deposits in leptosols group which increase percentage from 12.84 to 46.44 from lithic to eutric class which believe to decrease the hardness of parent rock which in the first soil class are composed dominantly of Igneous and metamorphic into hard stiff limestone of low resistivity for the eutric soil class.

The clacisols soil group is dominated by stratigraphic sequence rich in carbonate components. Cretaceous, Tertiary and Quaternary strata represent the main essential parent rocks for haplic calsiols class (yermic) of $98.93 \%$, while the haplic calsisols class comprises mainly of Paleozoic composed of $73.44 \%$. The carbonate rich Formations for both soil classes are significant from Pre-Carboniferous, and Carboniferous strata, Cretaceous from Halal/Raha Formation into Sudr Formation Eocene from Thebes to Tanks/Maadi Formation of carbonate rich strata, The calcareous rock fragments on the surface distinguished the yermic class may believe in inherent consistency of younger components of carbonate Formations. Arenosols mostly of sand dunes and clastic quaternary are situated in an area of noth fold belt occupies the depression area between the systematic north east fold belts. Calcaric arenosols class rich of quartz expresses intensive process of weathering and transported agents for this type of soils. Gleyic solonchaks is the waterlogged soil appear along the coastline of the Mediterranean Sea, where seepage and Sabkha are development with a salt surface horizon. Unconsolidated fine to medium grained materials refers to regosols soil group which disturbed along other soil group mainly composed of more than $73 \%$ of quaternary clastic deposits and from 5 to $9 \%$ of hard rock units of either basements for eutric soil class or of the Tertiary of Thebes, Darat, Khaboba, Mokattam, and Maadi/Tanka Formations of mostly marine hard limestone rock and shale of Eocene periods for calcaric regosols class.

\section{References}

Abdel Rahman, S., Onsi, H. (1996) Application of Remote Sensing and GIS For Soil Mapping of ElHasana Central Sinai, Egypt, ISPRS Proceedings, Vienna, 31 $B 4$, 1-6.

Alsharhan, A. S., Salah, M. G. (1996) Geologic setting and hydrocarbon potential of north Sinai, Egypt, Bulletin of Canadian Pert. Geol., 44, 615-631.

Ammar, G., Afifi, T. (1992) Early-Late Cretaceousre of complex facies in north Sinai, Egypt (a model for oil exploration). 11th EGPC Exploration Seminar, Egypt, 1, 577-587.

Batjes, N. H., Fischer, G., Nachtergaele, F.O., Stolbovoy, V. S., van Velthuizen, H. T. (1997) Soil data derived from WISE for use in global and regional AEZ studies'. Interim. Report IR 97-025. (FAO/IIASA/ISRIC: IIASA, Laxenburg, Austria).

Coleman, D. C., Crossley, J. D., Hendrix, P. F. (2004) Fundamentals of Soil Ecology 2 2nd ed, E Isevier.

ECSC-EEC-EAEC (1985) Soil map of the European Communities 1:1 000 000, Luxembourg, 124 pp. and paper maps.

EGPC (1986) Activity of oil exploration in Egypt (1886-1986). 8th EGPC Exploration Seminar, Egypt.

Einsele, G. (1992) Sedimentary Basins: Evolution, Facies and Sediment Budget.Springer-Verlag Berlin Heidelberg, Germany

EI Gaby, S., List, F. K., Tehrani, R. (1990)The basement complex of the Eastern Desert and Sinai, in R Said (ed). The Geology of Egypt. Rotterdam Brookfield, Balkema, 175-184.

European Commission Joint Research Centre (2005) Soil atlas of Europe.

FAO (1990) Soil map of the world: Revised legend. World Soil Resources Report 60, Food and Agriculture Organization of the United Nations, Rome. 
FAO (1991) Soil map of Africa one sheet (bar scale $0-2400 \mathrm{Km})$

FAO (2006) Guidelines for Soil Description, 4th ed. FAO, Rome.

FAO/UNESCO (1971-1981) Soil map of the world 1, 5 000 000. 10 Volumes. Paris, UNESCO.

FAO/UNESCO/ISRIC (1997) Soil map of the world, revised legend with correction and updates, Technical paper 20,1-146

FAO/ISRIC/ISSS (1998) World Reference Base for Soil Resources, World Soil Resources Reports, 84, Rome.

Geologic map of Egypt (1981) Sclae 1: 2000 000. The Egyptian geological survey and mining authority,

Hassan, M. A., Hashad, A. H. (1990) Precambrian of Egypt, in R Said (ed). The Geology of Egypt 201245. RotterdamlBrookfield: Balkema.

International Soil Reference and Information Centre (ISRIC) (2005) Updated global and national soils and terrain digital databases (SOTER).

Issawi, B., El Hinnawi, M., Francis, M., Mazhar, A. (1999) The Phanerozoic Geology of Egypt: A Geodynamic Approach., Egyptian Geol. Survey S. P. 76, 1-462.

IUSS Working Group WRB (2006) World reference base for soil resources 2006, World Soil Resources Reports No. 103. FAO, Rome.

Jones, A., Breuning-Madsen, H., Brossard, M., Dampha, A., Deckers, J., Dewitte, O., Gallali, T., Hallett, S., Jones, R., Kilasara, M., Le-Roux, P., Micheli, E., Montanarella, L., Spaargaren, O., Thiombiano, L., Van- Ranst, E., Yemefack, M., Zougmore, R. (2013). Soil Atlas of Africa. European Commission, Publications Office of the European Union, Luxembourg.

Leeder, M. (2012) Sedimentology and Sedimentary Basins: From Turbulence to Tectonics, Blackwell Publishing, 350, Main Street, Malden, MA 021485020, USA.

Nachtergaele, F. (2010) The classification of Leptosols in the World Reference Base for Soil Resources, 19th World Congress of Soil Science, Soil Solutions for a Changing World Brisbane, Australia. 25-27

Nichols, G., (2009) Sedimentology and Stratigraphy :2nd Ed, Wiley-Blackwell, John Wiley \& Sons Ltd, The Atrium, Southern Gate, Chichester, West Sussex, PO19 8SQ, UK.

Pansu, M., Gautheyrou, J. (2006) Handbook of Soil Analysis: Mineralogical, Organic and Inorganic Methods, Springer-Verlag Berlin Heidelberg.

Said, R. (1962)The Geology of Egypt. Elsevier.

Egypt. J. Soil. Sci. Vol. 58, No. 2 (2018)
Said, R. (1971) Explanatory Notes to Accompany Geological Map of Egypt, Geol. Surv. of Egypt, Cairo, 56, 1-123.

Said, R. (1990) The Geology of Egypt, Rotterdam Brookfield, Balkema.

Saleh, A. M., Belal, A. B., Arafat, S. M. (2013) Identification and mapping of some soil types using field spectrometry and spectral mixture analyses: a case study of North Sinai, Egypt, Arab J Geosci 6,1799-1806

Schoeneberger, P. J., Wysocki, D. A., Benham, E. C., Broderson, W. D. (2002) Field book for describing and sampling soils. Version 2.0. Lincoln, USA, National Soil Survey Center, Natural Resources Conservation Service, USDA.

Schlumberger (1984) Well evaluation conference, Sinai, Egypt, 44-52.

Tawdros, E. E. (2001) Geology of Egypt and Lybia, A. A. Balkema Publishers, USA.

United States Department of Agriculture (USDA) Soil Survey Staff (1975) Soil taxonomy. Agricultural Handbook No. 436. Washington, DC

United States Department of Agriculture (USDA) Soil Survey Staff (1999). Soil taxonomy, a basic system of soil classification for making and interpreting soil surveys. 2nd edition. Agricultural Handbook No. 436. Washington, DC.

United States Department of Agriculture (USDA) Soil Survey Staff (2003). Keys to soil taxonomy. 9thed. Washington, DC, Natural Resources Conservation Service, USDA.

World reference base for soil resources (2014) International soil classification system for naming soils and creating legends for soil maps, FAO, Viale delle Terme di Caracalla 00100 Rome, Italy.

Yigini, Y., Panagos, P., Montanarella, L. (2013)Soil Resources of Mediterranean and Caucasus Countries Extension of the European Soil Database, Joint Research Centre of the European Commission, Via Enrico Fermi 2749, TP 280, 21027 Ispra (VA), Italy.

Waltham, T. (2009) Foundations of Engineering Geology, 3rd ed. Taylor \& Francis 270 Madison Avenue, New York, NY 10016.

(Received: 11/12/2017; accepted: $1 / 2$ / 2018 ) 
نادر أحمد إدريس ومايسة نبيه طانه

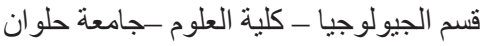

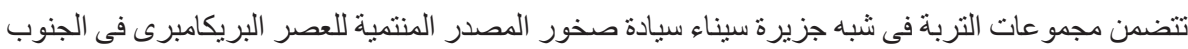

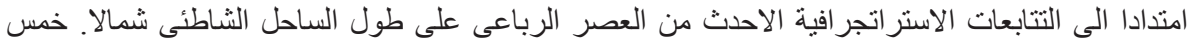

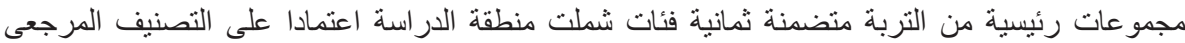

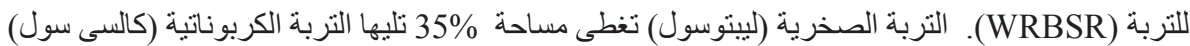

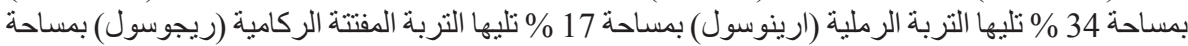

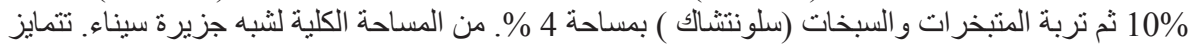

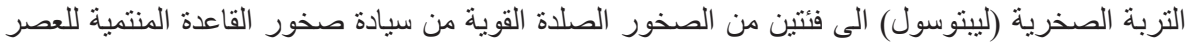

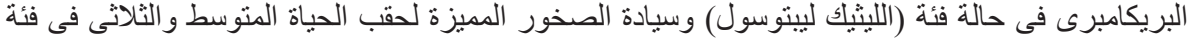

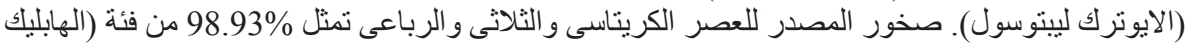

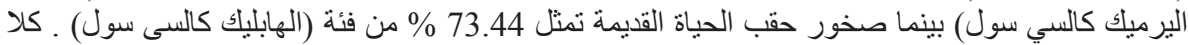

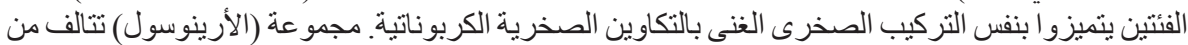

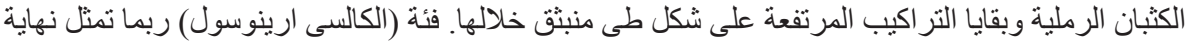

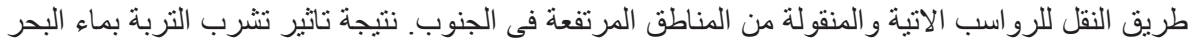

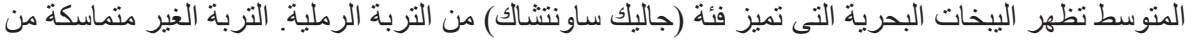

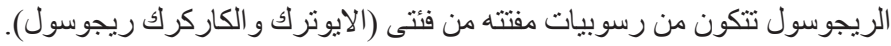

